\title{
Willingness to Pay for Kubah National Park: Evidence from the Contingent Valuation Method
}

Nor Afiza Abu Bakar, Dayang Affizzah Awang Marikan, Salbiah Edman, Dayang Haszelinna Abang Ali

To Link this Article: http://dx.doi.org/10.6007/IJARBSS/v11-i1/8541

DOI:10.6007/IJARBSS/v11-i1/8541

Received: 10 December 2020, Revised: 02 January 2020, Accepted: 16 January 2021

Published Online: 29 January 2021

In-Text Citation: (Abu Bakar et al., 2021)

To Cite this Article: Abu Bakar, N. A., Marikan, D. A. A., Edman, S., \& Ali, D. H. A. (2021). Willingness to Pay for Kubah National Park: Evidence from the Contingent Valuation Method. International Journal of Academic Research in Business and Social Sciences, 11(1), 500-514.

\section{Copyright: (c) 2021 The Author(s)}

Published by Human Resource Management Academic Research Society (www.hrmars.com)

This article is published under the Creative Commons Attribution (CC BY 4.0) license. Anyone may reproduce, distribute, translate and create derivative works of this article (for both commercial and non-commercial purposes), subject to full attribution to the original publication and authors. The full terms of this license may be seen at: http://creativecommons.org/licences/by/4.0/legalcode

Vol. 11, No. 1, 2021, Pg. 500 - 514

Full Terms \& Conditions of access and use can be found at http://hrmars.com/index.php/pages/detail/publication-ethics 


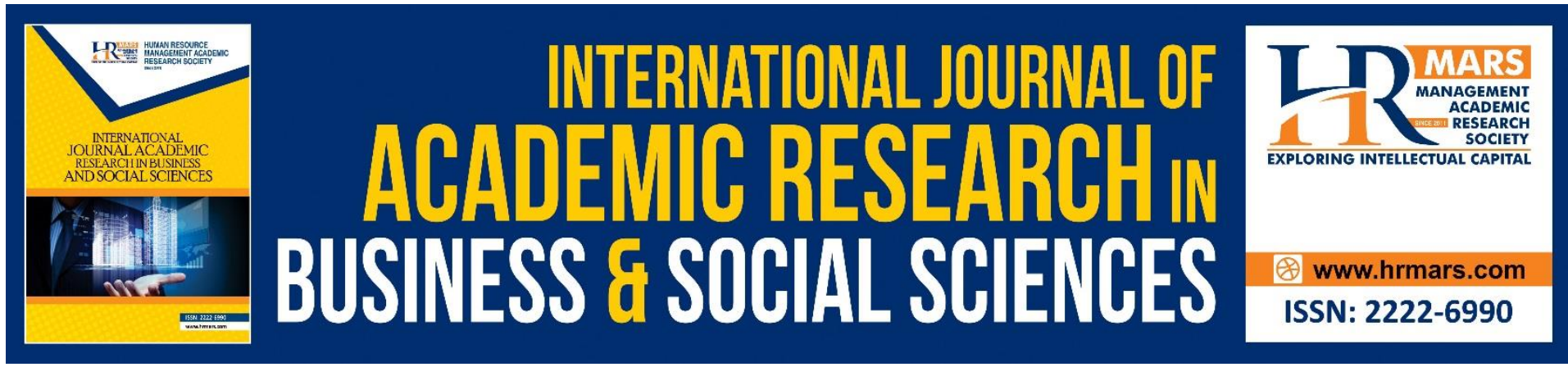

\title{
Willingness to Pay for Kubah National Park: Evidence from the Contingent Valuation Method
}

\author{
Nor Afiza Abu Bakar, Dayang Affizzah Awang Marikan, Salbiah \\ Edman, Dayang Haszelinna Abang Ali
}

Faculty of Economics and Business, Universiti Malaysia Sarawak (UNIMAS), Malaysia Centre for Policy Research and International Studies (CenPRIS), Universiti Sains Malaysia

(USM), Malaysia

\section{Abstract}

The purpose of this study is to estimate Kuching residents' (non-visitors) willingness to pay (WTP) for the conservation of Kubah National Park, Sarawak. In order to answer the research objectives in this study, Contingent Valuation Method (CVM) was put into application as the elicitation method and there were 160 respondents who involved in this data collection, where the random sampling method was executed. A dichotomous choice CVM (DC-CVM) was adopted and logit models were used to analyze the CVM analysis. The empirical results indicated that as the price increases, the probability in saying ' $Y e$ s' $^{\prime}$ decreases. The minimum estimated mean for the WTP is an increment of $4.38 \%$ (RM0.44) while the maximum estimated mean is an increment of $200.24 \%$ (RM20.24). In addition, work status, education level attainment and income show positive and significant results.

Keywords: Total Economic Value, Contingent Valuation Method, Willingness to Pay, National Park, Conservation Attributes

\section{Introduction}

National parks play an integral role in the conservation and preservation of biodiversity and the provision of other benefits associated with the maintenance of ecological integrity (Stolten \& Dudley, 2010; Bhatt \& Bhat, 2016). It raises opportunities for people to learn and explores the diverse environments. Natural environment such as forest, wetlands, protected areas and national parks are well known as one of the largest sources that give significant contributions to community and affects human survival in this world. Natural ecosystem is also important to the economic activities in tourism industry specifically ecotourism as it contributes to the development of economic, social and environmental dimensions. Ecotourism, usually a form of nature-based tourism is usually claimed to be one of the fastest growing segments of the tourism market globally (Tisdell, 2003). According to Sangpikul (2017), the increased demand to experience with pure nature or undisturbed natural areas helps the growth of ecotourism.

According to Wunder (2000), nature tourism is a significant tool that contributes to employment and income in underdeveloped, biodiversity-rich. For instance, a project that is 
related to tourism industry conducted by The World Bank is having an impact on the local economy and instantly provide a job opportunity for the local community. By creating employment for local people in tourism, they are able to receive tangible economic benefits from the presence of wildlife alive (The World Bank, 2017). Malaysia is widely known with its vast arrays of ecosystems and tropical rainforests that are rich with biodiversity, flora and fauna and unique natural heritage. Malaysia's flora diversity is not absolutely known, but it was estimated to reach around 15, 000 species. The two Malaysia states located on Borneo Island is estimated to have around 12,000 species. Malaysia has gained immense benefits of the forest resources.

The scope of this study is narrowed down to the protection and conservation of a national park in Sarawak, particularly Kubah National Park (KNP). Willingness to pay (WTP) of nonvisitors are measured to study and observe the value and its perceptions towards natural resources; national park to the public.

\section{Problem Statement}

Over the years, economic success has been inevitably linked to natural resource exploitation. From dams and mines to industrial industry, economic forces have transformed natural landscape across the region at a scale and intensity that are historically unprecedented (Kwok et al., 2018). The authors also stated that the increasing pace of environmental transformation has had significant ecological repercussions and the rising economic growth does not reflect its abilities to conserve biodiversity and as consequences, protected areas have been downgraded as results from human activities.

One of the solutions that policymakers decided to impose to preserve the environments, for example, national parks; is by charging fees to the users. Parks and protected areas could allure and attract significant public interest. Therefore, visitors are willing to invest money, time and effort to witness and experience the mother nature's close in person. Many factors determine the nature of this experience, such as; condition of the resources, logistic support available in the park and locally the attitudes of the public.

The majority of the environmental goods and services such as national parks, wildlife populations, clean air and water are categorized in non-market value and are hardly traded in the market. According to Baker and Baker \& Ruting (2014), policymakers often faced with difficulties to impose charges to improve the condition of the environment affected by ecological damages and degradation of natural resources. To put certain prices or charges on non-market values are challenging as it may not reflect the actual values of the goods and services.

There is uncertainty whether the entrance fee charged in Kubah National Park is set by the market and it may not capture the true economic value that people placed on the protected areas. Therefore, it is crucial to obtain information and understand the concept of supply and demand to predict the true value of the park to the visitors and therefore appropriate fee can be determined to charge the visitors.

\section{Total Economic Value (TEV)}

The concept of total economic value (TEV) first came into general use in the late 1980s and early 1990s (Emerton, 2016). TEV is a framework that is widely used by economists to identify 
and to categorize environmental benefits. Besides that, TEV also takes into account subsistence and non-market values, ecological functions and non-use benefits. TEV distinguishes into two elements; use values and non-use values. Use values consist of direct values, indirect values and option values while non-use values consist of existence value and bequest value. According to Haefele et al. (2016), existence value is the utility or benefit that accrues to an individual from simply acknowledging that a resource, for an example, national park, exists, even if the individual never expects to visit or see or utilize the resources. Contradict to bequest value, it measures the benefit or utility an individual enjoys from knowing that a resource will be preserved for future generations.

\section{Willingness to Pay (WTP)}

Historically, the term willingness to pay (WTP) has been used to describe consumer's acceptance to pay for products or services for a maximum price given (Gall-Ely, 2009). WTP is an important component of consumer demand as it offers the best possible margin of price and to set a price. Understanding WTP and its influencing factors is crucial as it provides direction and opportunities for particular parties to optimize both sales volumes and margins.

\section{Contingent Valuation Method and Willingness to Pay}

There are many environmental valuation studies in the literature that used DC-CVM, Choice Modelling (CM) and TCM to elicit WTP. Samdin et al. (2013) applies dichotomous choice Contingent Valuation Method (DC-CVM) to access the net economic values of ecotourism resources in Taman Negara. Due to inappropriate entrance fee charges, it creates several issues in parks, and the most common is a lack of income generation. Hence, this study's objective is to investigate factors that determine non-visitors' willingness to pay to Taman Negara as it is important for any development plan in protected areas and national park. Research conducted by Limaei et al. (2016) aims to evaluate the economic values of the Saravan Forest Park, north of Iran and CVM is used for this study. The variables used in this study are entrance fee, monthly income, non-governmental organization (NGO) membership, moralizing view on environmental and natural use resources and length of stay to elicit WTP. The tests applied are linear logit regression, linear logit model and Cronbach's Alpha Method and the findings indicate that all independent variables have a significant effect on WTP.

Furthermore, research done by Wrobel and Kozlowski (2011) seeks to determine international tourists' WTP for entry fees in the Annapurna Conservation Area (ACA), Nepal. CVM survey is used to collect the data and variables used are the amount of money spent on travel and leisure per year, the main motivation for the visit being the trekking experience, tour guide usage, experience in ACA, number of visits and the amount of time spent in ACA and their level of environmental commitment. Pearson chi-square and basic frequency statistical tests is performed in this study to determine the relationship between these variables. The Pearson chi-square test result indicates that rating of trekking as being the most important motivation to visit ACA has a positive relationship with WTP.

In addition, Ghanbarpour et al. (2011) estimates the recreational value of the Baba Aman Natural Park in Northeast Iran and employed CVM to protect, restore and improve the area for a better decision-making. CVM is employed in this study and multiple regression and bivariate analysis are used and the results show that income and education are the most significant variables that affects non-visitors' WTP for entrance fee and the average WTP 
estimated is 1.5 and 2 times more than the current entrance fee. Similarly, Khan (2006) conducted a study to estimate the benefits of Margalla Hills National Park and to value the recreational benefits. However, this study used a combination of CVM and TCM to measure the recreational values of the park.

\section{Methodology}

The survey in this study was conducted in Kuching's resident's area using random sampling. Simple random sampling method is chosen for this study as it allows each individual to be chosen entirely by chance and each member of the population has an equal chance and probability of being included in the sample from a larger group. The target respondents of this study are the residents of Kuching's area and aims to collect a sample between 150 to 200 respondents. Sample data consisted of 160 respondents. According to Limaei (2016), sample size is an important issue for proper and reliable estimation of the economic value of the recreational site. The questionnaires are then distributed at Kuching Waterfont, Kuching's town and housing areas.

Research instrument used in this study is survey questionnaire, specifically Contingent Valuation Method and Likert Scales. The questionnaire designated consist of Section I (Introduction), Section II (Attitudinal Information), Section III (Contingent Valuation Questions) and Section IV (Background Information). The targeted respondents in this study were the Kuching residents (non-visitor) and the questionnaires are distributed at Kuching Waterfronts Kuching's town and housing areas. Statistical Package for Social Sciences (SPSS) was utilized to analyze the respondents' data. The test used to analyze the results are descriptive statistics, explanatory factor analysis (EFA), reliability test, and logit model. Descriptive analysis, such as frequencies and mean were applied to obtain information on socio demographic and economic profiles and respondents as well as their values of WTP.

\section{Design Stages of Contingent Valuation Method (CVM)}

This section exhibits on how the method is established and distinguish the design stages of the CVM.

\section{Figure 1: Design Stages of CVM}

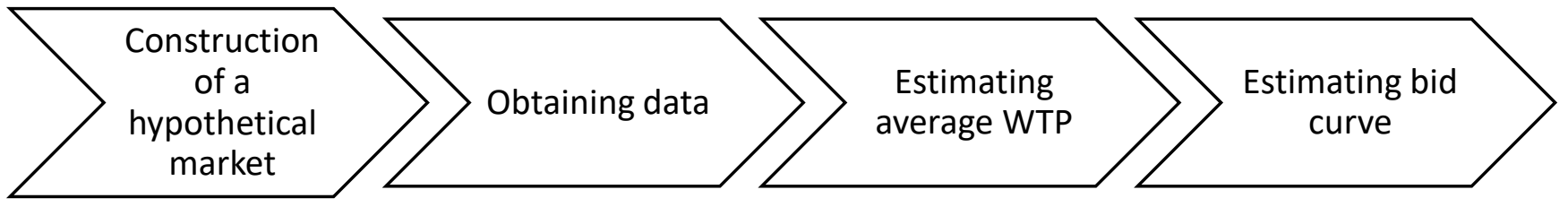

\section{Construction of A Hypothetical Market}

The hypothetical market should reflect a scenario that correlates with a real situation for the respondents to fully understand the bottom of the issues that it's currently facing. It should include a brief introduction of the place and the concerns or dilemma of the researcher and why it is important to overcome the concerns mentioned. In this study, the scenario describes about Kubah National Park's gazettement purposes and the authority's effort to sustain its well-being for protection conservation of the park. Then, the respondents will be entailed to state their WTP based on the scenario described. 


\begin{abstract}
Scenario
Kubah National Park contains among the richest rainforests on earth. It is known to international botanists as the "World of Palms". The park offers a variety of ecotourism activities such as forest walk, bird watching, frog spotting, picnicking and etc. The main objective of the park is the conservation of wildlife community and plants for sustainable use of ecotourism activities in the future. Currently, the park faces several issues such as illegal logging, oil erosion, illegal collection of jungle products and poaching. In order to combat these issues, the management and conservation operation requires funds to cover the on-going costs. One way to gather funds it to increase entrance fees to Kubah National Park. Currently, visitors are charged RM10 (local) and RM20 (foreigner) per entry to the park/centre.
\end{abstract}

\title{
Obtaining Data
}

Simple random sampling method is chosen for this study as it allows each individual to be chosen entirely by chance and each member of the population has an equal chance and probability of being included in the sample from a larger group. Then, the individual selected will go through a personal interview (person to person) where the interviewer will explain further on why this study is conducted. Apart from that, the interviewer too would be able to engage and communicate with the interviewee and help them if there are any difficulties occur faced by the interviewee to prevent from misunderstanding when answering the questionnaire.

\section{Valuation Measure Sought}

Maximum willingness to pay (WTP) is adopted as the sought valuation measure for an improvement or enhancement of the quality of the environment to avoid further declines in environmental quality.

\section{Bidding Price for Entrance Fees}

There are four different starting bids in this study to minimize starting point bias; where maximum WTP can be influenced by the starting bid in the auction process. Next, the current entrance fee charged is RM10 for local and RM20 for foreigner per entry is set as the price base. In this context, dichotomous choice is adopted where the respondent responds to the first amount of bid and face another question that involves another bid amount, regardless of how high or low depending on the first question. It requires the respondents to answer 'Yes' or 'No' (positive or negative response) to the respective questions.

\section{Results}

\section{Descriptive Analysis}

Table 1 shows the summary of respondent background information. There are an almost equal number of males and females in which females contributed to $51 \%(82)$ in this research while males contributed to $49 \%$ (78) with the only differences of four numbers. Most of the respondents (37.0\%) were between 18 to 25 years old, followed by the age group 20 to 35 years old (31.0\%). In terms of educational background, $52.0 \%$ of the respondent had completed tertiary education followed by $41.0 \%$ and $6.0 \%$ had attained secondary school and primary school, respectively. Based on the Table 1, most of the respondents are employed; $94 \%$ which is equivalent to 150 . Out of 160 , only $2 \%$ (3) that are unemployed or still searching for a job while the reminding is either retired $(2 \%)$ or is still studying in primary or secondary 
education (2\%). In term of income, majority of respondents (43.7\%) earned an income between RM2,001 to RM4,000. This was followed by income group lower than RM2,000 (38.1\%). This particular demographic characteristic may influence the results of the WTP and it will be tested later in the WTP analysis.

Table 1: Respondents' Background

\begin{tabular}{|c|c|c|}
\hline Characteristics & Percentage (\%) & $\mathbf{n}$ \\
\hline \multicolumn{3}{|l|}{ Gender } \\
\hline Male & 49.0 & 78 \\
\hline Female & 51.0 & 82 \\
\hline \multicolumn{3}{|l|}{ Age } \\
\hline $18-25$ & 37.0 & 60 \\
\hline $26-35$ & 31.0 & 49 \\
\hline $36-45$ & 14.0 & 23 \\
\hline $46-55$ & 13.0 & 21 \\
\hline $56-65$ & 4.0 & 6 \\
\hline $65+$ & 1.0 & 1 \\
\hline \multicolumn{3}{|l|}{ Education Level } \\
\hline No formal education & 1.0 & 2 \\
\hline Primary school & 6.0 & 9 \\
\hline Secondary school & 41.0 & 65 \\
\hline Tertiary Education & 52.0 & 84 \\
\hline \multicolumn{3}{|l|}{ Occupation } \\
\hline Employed & 94.0 & 150 \\
\hline Unemployed & 2.0 & 3 \\
\hline Retired & 2.0 & 3 \\
\hline Others & 2.0 & 4 \\
\hline \multicolumn{3}{|l|}{ Monthly Gross Income } \\
\hline Lower than RM2,000 & 38.1 & 61 \\
\hline RM 2,001- RM4,000 & 43.7 & 70 \\
\hline RM 4,001-RM6,000 & 11.9 & 19 \\
\hline RM6,001- RM8,000 & 1.9 & 3 \\
\hline $\mathrm{RM} 9,001$ - more than $\mathrm{RM} 10,000$ & 4.4 & 7 \\
\hline
\end{tabular}

Based on the Table 2, the overall results show that majority of the respondents agreed with the roles and the functions of Kubah National Park. Out of 20 attributes associated with the national Parks roles and functions, only three attributes, which are "National Parks function as places for spiritual fulfilment", "National Parks function as place of socializing" and "National Parks are places for commercial development of natural resources (such as oil, timber, minerals)" that has percentage below $50 \%$. The remainder attributes from the finding shows that over $60 \%$ of participants are either agree or strongly agree. This indicates that the Kuching's residents that participated in this study has a positive perception towards the roles and the functions of Kubah National Parks. 
Table 2: Descriptive Analysis of Kubah National Park's Roles and Functions

\begin{tabular}{|c|c|c|c|c|}
\hline \multirow{2}{*}{ Attributes } & \multicolumn{2}{|c|}{ Percentage (\%) } & \multicolumn{2}{|c|}{ Descriptive } \\
\hline & Agree & Disagree & Mean & S.D \\
\hline $\begin{array}{l}\text { 1. National Parks are to protect endangered species of } \\
\text { flora, fauna and wildlife habitats. }\end{array}$ & 53.8 & 0.6 & 4.2 & 0.7 \\
\hline $\begin{array}{l}\text { 2. Protecting the natural environment and wildlife } \\
\text { should be the first priority of National Parks }\end{array}$ & 50.6 & 1.9 & 4.2 & 0.8 \\
\hline $\begin{array}{l}\text { 3. National Parks function to preserve biological } \\
\text { diversity. }\end{array}$ & 50.6 & - & 4.2 & 0.7 \\
\hline $\begin{array}{l}\text { 4. National Parks are places for protecting the natural } \\
\text { environment and wildlife. }\end{array}$ & 50.0 & - & 4.3 & 0.6 \\
\hline $\begin{array}{l}\text { 5. National Parks are places to protect the scenic beauty } \\
\text { of nature. }\end{array}$ & 54.4 & 0.6 & 4.3 & 0.7 \\
\hline National Parks are places for learning about nature. & 51.2 & 1.9 & 4.1 & 0.8 \\
\hline $\begin{array}{l}\text { 7. National Parks are places for protecting cultural and } \\
\text { historical heritage }\end{array}$ & 46.3 & 6.3 & 4.0 & 0.9 \\
\hline $\begin{array}{l}\text { 8. National Parks are places for scientific research and } \\
\text { monitoring }\end{array}$ & 50.9 & 3.1 & 4.0 & 0.8 \\
\hline Parks are tourist destinations. & 51.9 & 5.0 & & 0.8 \\
\hline 10. National Parks are places for all living things to exist. & 51.9 & 5.0 & 3.9 & 0.8 \\
\hline 11. National Parks help to reduce global warming. & 54.4 & 10.0 & 3.8 & 0.9 \\
\hline $\begin{array}{l}\text { 12. National Parks are reserves of natural resources for } \\
\text { future use. }\end{array}$ & 50.0 & 3.8 & 4.1 & 0.8 \\
\hline $\begin{array}{l}\text { 13. Visiting National Parks can enhance people's love to } \\
\text { the country }\end{array}$ & 49.4 & 8.3 & 3.8 & 0.8 \\
\hline 14. National Parks provide economic benefits. & 51.2 & & & 0.8 \\
\hline 15. National Parks are places for people's enjoyment. & 51.2 & 8.8 & 3.7 & 0.9 \\
\hline $\begin{array}{l}\text { 16. National Parks function as places for spiritual } \\
\text { fulfilment }\end{array}$ & 35.6 & 16.9 & 3.3 & 1.0 \\
\hline 17. National Parks are places for recreational activities & 61.9 & 3.1 & 4.0 & 0.7 \\
\hline $\begin{array}{l}\text { 18. National Parks are places to be protected for the } \\
\text { enjoyment of future generations. }\end{array}$ & 54.4 & 2.5 & 4.2 & 0.7 \\
\hline 19. National Parks function as place of socializing & 46.9 & 10.0 & 3.7 & 2.5 \\
\hline $\begin{array}{l}\text { 20. National Parks are places for commercial } \\
\text { development of natural resources (such as oil, } \\
\text { timber, minerals). }\end{array}$ & 29.4 & 24.4 & 3.0 & 1.1 \\
\hline
\end{tabular}

Note:

1. Survey item is adapted from Afiza, A. B. N et al. (2016).

\section{Exploratory Factor Analysis (EFA)}

EFA was used to identify if there is any existence of simple patterns among the variables studies. Principal component factor analysis was conducted (with Varimax rotation) on variables measuring NP's roles and function. The result of Kaiser-Meyer-Olkin Measure of Sampling Adequacy (KMO) is 0.826 which indicates that there is a positive relationship between the variables and thus is relevant for factor analysis or principal componentfactoring. On top of that, Bartlett's shows a significant result (Chi Square $=1149 / 242$, 
$\mathrm{p}<0.001)$. The result of the factor analysis is presented as below and there are 4 significant factors identified in this analysis.

Table 3: Varimax Factor Analysis of Kubah National Park's Roles and Functions (NonVisitors)

\begin{tabular}{|c|c|c|c|c|c|}
\hline Variables & F1 & F2 & F3 & F4 & F5 \\
\hline $\begin{array}{l}\text { 1. National Parks are to protect endangered species of } \\
\text { flora, fauna and wildlife habitats. }\end{array}$ & .868 & & & & \\
\hline $\begin{array}{l}\text { 2. Protecting the natural environment and wildlife should } \\
\text { be the first priority of National Parks. }\end{array}$ & .860 & & & & \\
\hline $\begin{array}{l}\text { 4. National Parks are places for protecting the natural } \\
\text { environment and and wildlife. }\end{array}$ & .631 & & & & \\
\hline 3. Nationals Parks function to preserve biological diversity. & .626 & & & & \\
\hline 6. National Parks are places for learning about nature. & .537 & & & & \\
\hline $\begin{array}{l}\text { 5. National Parks are places to protect the scenic beauty } \\
\text { of nature. }\end{array}$ & .532 & & & & \\
\hline $\begin{array}{l}\text { 12. National Parks are reserves of natural resources for } \\
\text { future use. }\end{array}$ & & .761 & & & \\
\hline $\begin{array}{l}\text { 13. Visiting National Parks can enhance people's love to } \\
\text { the country. }\end{array}$ & & .750 & & & \\
\hline 14. National Parks provide economic benefits. & & .683 & & & \\
\hline 11. National Parks help to reduce global warming. & & .614 & & & \\
\hline 18 National Parks are places for recreational activities. & & .586 & & & \\
\hline $\begin{array}{l}\text { 7. National Parks are places for protecting cultural and } \\
\text { historical heritage. }\end{array}$ & & & .786 & & \\
\hline 10. National Parks are places for all living things to exist. & & & .709 & & \\
\hline $\begin{array}{l}\text { 8. National Parks are places for scientific research and } \\
\text { monitoring. }\end{array}$ & & & .679 & & \\
\hline $\begin{array}{l}\text { 16. National Parks function as places for spiritual } \\
\text { fulfilment. }\end{array}$ & & & & .741 & \\
\hline 17. National Parks are places for recreational activities. & & & & .601 & \\
\hline 9. National Parks are tourist destination. & & & & .551 & \\
\hline $\begin{array}{l}\text { 20. National Parks are places for commercial development } \\
\text { of natural resources (such as oil, timber, minerals). }\end{array}$ & & & & .535 & \\
\hline 19. National Parks function as place of socializing. & & & & & .742 \\
\hline
\end{tabular}

1. Extraction Method: Principal Component Analysis. Rotation Method: Varimax with Kaiser Normalization. a. Rotation converged in 9 iterations.

2. Survey item is adapted from Afiza, A. B. N et al. (2016).

Reliability test was conducted, and the values of the Cronbach's alpha obtained from the analysis for Factor 1, Factor 2, Factor 3 and Factor 4 were 0.869, 0.779, 0.713 and 0.577 respectively. 


\section{Logit Model's Empirical Results}

Logit regression analysis was put into application to explain the relationship between one dependent binary variable and one or more nominal, ordinal, interval or ratio-level independent variables. Prior to this analysis, preliminary analysis was conducted to check the reliability of measures and evaluating the effectiveness of any manipulations, examining the distributions of individual variables and identifying outliers. Preliminary analysis unveils that not all independent variables used are either significant nor highly correlated with other variables. Therefore, variables that are not significant were excluded from the final regression model to obtain the best logit model. Table 4 presents the results of preliminary regression and final regression model.

Table 4. Results of Preliminary Regression Model and Final Regression Model

\begin{tabular}{lll|ll}
\hline Variables & \multicolumn{2}{l|}{ Preliminary Regression Model } & \multicolumn{2}{l}{ Final Regression Model } \\
\cline { 2 - 5 } & Coefficient & t-value & Coefficient & t-value \\
\hline Constant & -6.926 & $0.001^{* *}$ & -7.140 & $0.001^{* * *}$ \\
Bid Price & -0.030 & $0.971^{*}$ & -.029 & $0.971^{* * *}$ \\
Gender & 0.322 & 1.380 & - & - \\
Age & -0.371 & $0.690^{*}$ & - & - \\
Work & 0.838 & $2.312^{*}$ & .882 & $2.415^{* *}$ \\
Education & 0.824 & $2.280^{* *}$ & 1.051 & $2.860^{* * *}$ \\
Income & 0.554 & $1.740^{* * *}$ & .351 & $1.420^{* *}$ \\
Factor 1 (NP's Roles) & 0.141 & $1.151^{* *}$ & .110 & $1.116^{*}$ \\
Factor 2 (Importance of NP's) & -0.089 & 0.915 & - & - \\
Factor 3 (Ecological Integrity) & 0.208 & 1.231 & - & - \\
Factor 4 (Believe) & -0.086 & 0.918 & - & - \\
\hline Chi squared & 56.780 & & 48.650 & \\
Pseudo R & 0.398 & & 0.350 & \\
Percentage Correct & $73.10 \%$ & & $73.10 \%$ & \\
\hline
\end{tabular}

Note: ${ }^{*}$ Significant at $10 \%$ level, ${ }^{* *}$ significant at $5 \%$ level and ${ }^{* * *}$ significant at $1 \%$ level.

From the table above, all the variables such as bid price, gender, age, work, education, income and all four factors gained from explanatory analysis were included and regressed for the estimation of the preliminary regression model. At this stage, the result shows that not all variables are significant; gender, age, Factor 2 (importance of NP's), Factor 3 (ecological integrity) and Factor 4 (believe). Hence, only statistically significant variables; bid price, work status, education and income are retained for the final logit regression model while the insignificant variables mentioned above were excluded for the next step analysis.

Final regression model is regressed, and the results are presented as above. Based on the estimation produced, demographic variables such as bid price, education, income and Factor 1 (NP's roles) were found to be important in the respondents' WTP estimation. 'Bid price' variable (BID) and 'education' variable (EDU) were found to be significant at $1 \%$ level. The coefficient of bid price shows a negative sign as implied, indicating that as the bid price increases, the tendency to say 'Yes' among the respondent declines. This is an example of the law of the demand whereby as the price increases, the demand for the goods and services would fall due to the price increment. As for education, the coefficient shows a positive sign 
as predicted. This designates the hypothesis that as one attained a higher education level, one will be able to improve thinking skill. This may be supported by Kamri et. al. (2017) where the authors stated that an increment in knowledge may ultimately influence an individual to think more rationally.

Next, work and income were found to be significant at $5 \%$ level and showed a positive sign as expected. This shows that respondent who is employed and has higher income is willing to pay to enter the national park despites of the price increment and to support this statement, a study conducted by Serefoglu (2018) found out that those who are working and has high income will have positive effects on paying higher entrance fee to support conservation and enjoying the park. Besides that, Factor 1 (NP's roles) was statistically significant, indicating that the respondents who were aware with the roles and functions of Kubah National Park are willing to pay for higher prices compared to respondents who responded less on Factor 2 (importance of NP's), Factor 3 (ecological integrity) and Factor 4 (believe).

In order to check for the overall fit of the model, chi-squared value and pseudo R2 values can be used for different measures of goodness fit. The estimated final regression model shows that the value of the chi-square is 48.65 with a $p$-values of less than 0.001 , indicating that the model as a whole fits significantly and there is significant relationship between the dependent and explanatory variables while Pseudo R2 obtained is 0.350 and the logit model classified 73.01\% for the correct percentage.

\subsection{Estimation of Willingness to Pay (WTP) for CVM}

The estimation of the bid curve's WTP was derived from the final regression analysis and is derived as below:

$W T P=\frac{\beta_{0}+\beta_{W O R K^{*}} W O R K+\beta_{E D U} * E D U+\beta_{I N C} * I N C+\beta_{F 1} * F 1}{\beta_{B I D}}$

$W T P=\frac{-7.140+0.882 * W O R K+1.051 * E D U+0.351 * I N C+0.110 * F 1}{0.029}$

Based on the estimation of WTP values, the calculated mean WTP ranges from $4.38 \%$ to $200.24 \%$ of price increment on the entrance fees for the respondents' logit model. Table 5 is depicted as shown below for the summary estimation of WTP respondents.

Table 5: Summary Estimation of WTP Respondents

\begin{tabular}{llll}
\hline & Minimum & Maximum & Mean \\
\hline Non-visitors & $4.38 \%$ & $200.24 \%$ & 53.46 \\
& RM0.44 & RM20.02 & RM5.35 \\
\hline
\end{tabular}

\section{Contingent Valuation Method (CVM) Analysis}

This section presents the main finding of dichotomous choice CVM where 160 questionnaires were distributed to the Kuching respondents to observe and to capture respondents WTP to enter Kubah National Park regardless of the price level. It is important to emphasize that when conducting CVM analysis, the bid value serves as one of the major players in explaining the responses obtained from the respondents to the bid question. Logit model analysis was 
executed to examine the answers given by the respondents. The results obtained from the logit analysis function as a basis analysis for the discussion and the output are gathered and compiled as shown below.

Based on the results in Table 6, 50\% of respondents answered 'Yes' to the first contingent valuation question despites of the differences in the bid price levels. This implies that $50 \%$ of the respondents were willing to pay for a higher price of entry level for the purpose of improvement in the quality of management and conservation of Kubah National Park. However, another $50 \%$ of the respondents refused to pay if the prices go up and this may be due to lack of awareness.

However, it is important for the respondents to be informed that the follow-up bid amount goes up to the proportion of individuals that shown a positive feedback. Table 7 depicts the respondents' responses to four different groups of bidding price and the responses of the Kuching resident's when there was an increment of prices after an individual answered 'Yes' to the first contingent valuation question. As expected, the proportion of positive answers goes down as the bid amount goes up across the different groups of bidding price. Results below shows that the percentage to say 'Yes' decreases as the bidding price increases. It could be observed that $65.0 \%$ of the Kuching residents rejected the highest bid price group (80\%) and only $35.0 \%$ were willing to pay higher offered amount for conservation and improvement of the Kubah National Park.

Table 6: Response of the First Contingent Valuation Question

\begin{tabular}{lll}
\hline Response & Frequency & Percent (\%) \\
\hline Yes & 80 & 50 \\
No & 80 & 50 \\
\hline Total & $\mathbf{1 6 0}$ & $\mathbf{1 0 0 . 0}$ \\
\hline
\end{tabular}


Table 7: Response of the First Contingent Valuation Question

\begin{tabular}{lllll}
\hline & \multicolumn{4}{c}{ WTP } \\
& & No (0) & Yes (1) & Total \\
\hline \multirow{3}{*}{ Bid Price (\%) } & $20 \%$ & $45.0 \%$ & $55.0 \%$ & 40 \\
& $40 \%$ & $34.2 \%$ & $65.8 \%$ & 38 \\
& $60 \%$ & $54.8 \%$ & $45.2 \%$ & 42 \\
Total & $80 \%$ & $65.0 \%$ & $35.0 \%$ & 40 \\
\hline
\end{tabular}

\section{Discussion}

The first objective of this research is to study the relationship between various socioeconomic indicators and how these characteristics may influence the respondents' WTP. It was found that there were five statistically significant variables (work status, education, income and national park's roles). The estimated signs for the coefficient of these four variables were in line with the hypothesized signs where work status, education attainment level, total monthly income and national park's roles shows positive signs, indicating that any increment or possession of these variables will positively impact respondents' willingness to pay. Based on the empirical results obtained, it can be seen that income level is one of the major contributors to WTP, indicating that as one's income level increases, their ability and willingness to pay will be higher and vice versa. Besides that, this study found evidence that respondents are willing to pay for higher entrance fee charges than the current fees available in Kubah National Park.

The second objective of the research question is answered when the bid price level showed a highly significant and negative relationship against WTP, portraying as price increases, the demand of goods or services decreases. For instance, in CVM analysis, the results show that the tendency of the respondents to depict 'No' was relatively high as the price increases. Hence confirming with the law of the demand, whereas the price increases, the demand or willingness to pay decreases.

The third objective of this study is to elicit respondents' attitudes and their willingness to pay towards the conservation and improvement of Kubah National Park. From the descriptive analysis, half of the respondents $(50 \%)$ agreed with the functions and the roles of the national park, depicting that the respondents are aware of the attributes mentioned in the study. Besides that, the estimated WTP derived from the analyses shows that in general total respondents are willing to pay higher entrance fee charges than the current fees in Kubah National Park. The estimated mean WTP ranged from RM0.44 to RM20.02, stipulating that the respondents are willing to pay for higher prices and encourage for the improvement and conservation of the park.

This study was conducted to gain an insight of factors or attributes of the respondents that may affect the decision-making process when it comes to protecting and conserving the natural resources in Sarawak, specifically in Kubah National Park. The finding reveals that the level of awareness among the respondents on the importance of the national park and its ecological integrity was relatively low. To tackle this issue, few initiatives can be taken such investing more in public education and communication program to instill self-awareness 
among the Kuching residents to change their perception and enhance their knowledge in environmental conservation.

\section{Conclusion}

The CVM has proved itself to be a versatile instrument that can be used to calculate almost anything. The variety in the valuation approach and the value ranges generated provides an opportunity to recognize the benefits and disadvantages of market valuation of environmental resources. The details from the CVM exercise, which was derived from real market behavior, was used. The knowledge that is gathered from the survey is gathered based on respondent's stated preferences. It is an important factor in deciding what the values of the goods and services are and how they should be measured. Respondents would comply with the principles offered to them if provided with the correct facts. This study showed that the non-visitors (non-users) are willing to pay more than the new entrance fees. The minimum and maximum additional to the entrance fees which is currently set at RM10 for Malaysian are RM0.44 and RM20.02, respectively. Whilst the mean for additional charges on top of the current entrance fees is estimated to be at RM5.35.

In conclusion, WTP can be used as tool for pricing policies in protected areas. The results from this study is crucial for future use as it may help the policymakers of the management of Kubah National Park to improve the effectiveness in managing the park in the most efficient ways. Hence, it is crucial for the management to improve the social safety of the area to convince the potential visitors that the park is indeed a safe place, even with the kids (with provisions from the parents).

\section{Acknowledgement}

This paper is funded by the Special Grant Scheme (SGS) grant: F01/SpGS/1557/2017 and supported by the Universiti Malaysia Sarawak (UNIMAS).

\section{Corresponding Author}

Nor Afiza Abu Bakar. Faculty of Economics and Business, Universiti Malaysia Sarawak (UNIMAS), 94300 Kota Samarahan, Sarawak, Malaysia. E-mail: abnafiza@unimas.my

\section{References}

Afiza, A. B. N., Radam, A., Samdin, Z., \& Yacob, M. R. (2016). Willingness to pay in Kubah National Park and Matang Wildlife Centre: A contingent valuation method. International Journal of Business and Society, 17(1), 131-144.

Baker, R., \& Ruting, B. 2014, Environmental Policy Analysis: A Guide to Non-Market Valuation. Productivity Commission Staff Working Paper, Canberra. https://www.pc.gov.au/research/supporting/non-market-valuation/non-marketvaluation.pdf

Bhatt, M. S., \& Bhat, M. Y. (2016). Valuation of national parks: An individual travel cost approach. International Journal of Multidisciplinary Research and Development, 3(3), 7-12.

Emerton, L. (2018). Economic Valuation of Wetlands: Total Economic Value. 10.1007/978-90481-9659-3_301.

Gall-Ely, M. L. (2009) definition, measurement and determinants of the consumer's willingness to pay: A critical synthesis and directions for further research. Recherche 
et Applications en Marketing, 24, 91-113.

Haefele, S. M., Kato, Y., \& Singh, S. (2016, April). Climate ready rice: Augmenting drought tolerance with best management practices. Field Crops Research, 190, 60-69.

Kamri, T., Ali, J. K., \& Harun, N. F. (2017). Willingness to Pay for Conservation of Natural Resources in Santubong National Park. Jurnal Manajemen dan Kewirausahaan, 1621.

Khan, H. (2006). Willingness to Pay for Margalla Hills National Park: Evidence from the travel cost method. The Labore Journal of Economics, 11(2), 43-70.

Limaei, S. M., Safari, G., \& Merceh, G. M. (2016). Recreational values of forest park using the contingent valuation method (Case study: Saravan Forest Park, North of Iran). Journal of Forest Science, 62, 452-462.

Samdin, Z., Aziz, Y. A., Radam, A., \& Yacob, M. R. (2013). Sustainability of ecotourism resources at Taman Negara National Park: Contingent valuation method. International Journal of Business and Society, 14(2), 235.

Sangpikul, A. (2017). Ecotourism impacts on the economy, society and environment of Thailand. Journal of Reviews on Global Economics, 6, 302-312.

Serefoglu, Coskun. (2018). Determination of visitors' willingness to pay to enter Karagol Natural Park of Ankara, Turkey. Ciência Rural. 48(7).

Stolton, S., and Dudley, N. (2010). Arguments for Protected Areas: Multiple Benefits for Conservation and Use. London: Earthscan.

Tisdell, C. (2003). Economic aspects of ecotourism: wildlife-based tourism and its contribution to nature. Sri Lankan Journal of Agricultural Economics, 5(1), 83-95.

World Bank. (2017). World Bank Annual Report. Retrieved from http://pubdocs.worldbank.org/en/908481507403754670/Annual-Report-2017WBG.pdf.

Wrobel, C., \& Kozlowski, A. (2011). Tourists' willingness to pay for entry to the Annapurna Conservation Area, Nepal. Himalayan Journal of Development and Democracy, 6(1), 97-109.

Wunder, S. (2000). Ecotourism and Economic Incentives: An Empirical Approach. Ecological Economics 32(3): 465-479. 